\title{
3.4. Historia Klinikoak euskaraz
}

\author{
Adrian Zelaia Nuñez \\ Aintzat Elkarteko kidea \\ adridu21@hotmail.com
}

\section{Aintzat aurkezpena}

Orokorrean espainol hutsean funtzionatzen duen administrazio publikoaren berebiziko atal honetan, euskara txoko txiki batzuetara mugatua dagoela ikusten dugu bai paziente, bai ikasle eta baita langileok ere. Muga hau gainera ahozkotasunera mugatzen da, praktikara eta erregistroetara iristen ez den espazioetara, salbuespenak salbuespen.

Osasun arloko lan munduan erdarak dira hizkuntza hegemonikoak: lan giroa, komunikazio formala, hizkuntza zientifiko-teknikoa, profesionalek idazten dituzten bilakaera-orriak, espezializazio planak... Faktore hauek guztiak, beste zenbaitzuez gain, ondorio bat dute: paziente euskaldunek ez dute bermaturik osasun arreta euskaraz jasoko dutenik.

Osasun arloko hezkuntzari dagokionez, ez dago ikasketak euskara hutsean burutzeko aukerarik ez lanbide heziketan ezta Unibertsitatean ere. Ipar Euskal Herriko ikasleek unibertsitate frantsesetara jo behar izaten dute ikasketak burutzera. Hego Euskal Herriko Unibertsitateek, alderdi batetik, ikasketa batzuk gaztelaniazsoilik eskaintzen dituzte, Nafarroako Unibertsitate Publikoko Erizaintza zein Medikuntza gradua kasu (Deustuko Unibertsitateari aipamenik egin ote zaio inon?). Eta, bestetik, euskaraz eskaintzen diren lerroek ez dute bermatzen ikasketak euskara hutsean burutzeko aukerarik, Euskal Herriko Unibertsitateko Medikuntza gradua kasu.

Behin eta berriro, Euskara Planaren arabera bete beharrekoak ziren hainbat minimo urratzen zirela ikusi dugu eta Osakidetzari etengabe eskatu zaio urraketa horiek zuzentzeko. Publikoki bestelakorik adierazten duten arren, urte hauetan ikusitakoak ikusita, argi eta garbi esan dezakegu euskara ez dela izan, eta ez dela gaur egun, inolaz ere lehentasunezko gaia ez Osakidetzako Zuzendaritza Nagusian, ez Zerbitzu Erakunde desberdinetako zuzendaritza organoetan, ezta tokian tokiko buruzagitzetan ere.

Agerikoa denez, euskara planen formatu teoriko zein praktikoa ez da batere eraginkorra. Botere harremanak, barne ustelkeria, paziente euskaldunekiko utzikeria, langile euskaldunekiko mespretxuak, etab. ezin dira albo batera utzi, eta 3. plan batek, egiturazko aldaketarik planteatu ezean, ez luke ezer aldatuko, ez luke inondik inora euskarazko osasun arretarik bermatuko.

Osakidetzak langileen gain jarri du zerbitzua euskalduntzeko pisu gehiena, baina euskararen normalizazio prozesuak zuzendaritzen inplikazio aktiboa behar du ezinbestean. Euskara erdigunera ekarri eta Osakidetzaren baitan hegemonizatzea dugu helburu. Kontratazioa, formakuntza, etab ahaztu gabe, baina bestelako ekimen folklorikoei (euskal kafe eta mendi irteerak, urtean behin euskarazko saio bat ematea...) dagokien eraginkortasun eta garrantzia urria azpimarratuz. Horretarako jaio ginen, horretarako ari gara langile, ikasle eta pazienteak antolatzen. 


\section{Alta txostenen dinamika}

Egoera guzti honetaz jakitun den langile talde batek euskalgintza berriari, herrigintzari eta euskal komunitateari bere ekarpena egin nahi izan zion Euskaraldiaren abagunea profitatuz: arreta era integralean euskaraz eskaini nahi izan du, bai ahozko komunikazioan eta bai idatzizkoan ere. Helburua argia zen: txosten klinikoak, pazienteekiko komunikazio formalaren elementu funtsezkoenak, euskaraz idazten hastea.

Gaixoei beraien ama-hizkuntzan emandako arreta da osasun arretarik onena, komunikazio eraginkorrean eta pazientearengan oinarriturikoa. Hortaz, euskarazko arreta formala zein informala kalitatezko arreta baterako gutxieneko baldintza bilakatzen hasi beharko gara.

Gaixoei bideratutako Larrialdietako txosten kliniko batzuk euskaraz idazteko planteamendua hasi genuen zenbait ospitaletan.

Honako eskaera bidali genien Gasteizko, Donostiako, Galdakaoko eta Zumarragako ospitaleetako zuzendaritzei:

"Euskaraldian zehar, eta baita bertatik aurrera ere, honakoa planteatzen dugu:

Urgentziatako zerbitzuan (baita urgentzia pediatrikoetan ere), 4 edo 5. prioritateko paziente euskaldunek, inongo jarraipen espezializaturik behar ez dutenek, edota jada mediku euskaldun baten jarraipena izango dutenek, euskarazko alta txostena jasotzea.

Jada zenbait langilek egiten dugun jarduera den arren, Izugarrizko aurrerapausoa litzateke gure ESIn ekimena hau ohiko jardunean txertatua edukitzea, eta hortaz ondo egiteko aukera edukita, honakoa behar genuke:

- Zerbitzu eta unitateburuei e-mail batean asmo hau adieraztea.

-Urgentziatako alta txostenen aurreidatziak euskaratzeko tresnak mahai gainean jartzea. Azken honentzako, gure prestutasun osoa adierazi nahi genizun, eta gure kabuz ere egiten hasiko garela aipatu."

ESI bakoitzean erantzun ezberdina jasota (ezezko borobilenetik zuzenean ez erantzutera), langileak izan ziren dinamika martxan jartzeko arduradunak. Behin martxan ginela ikusita, orduan hasi ziren zenbait zuzendaritza gure jarduna mugatu eta fiskalizatu nahian, onarpen partzialekin gehienbat. Donostian, adibidez, euskarazko txostenaren bukaeran espainolezko laburpen bat egitea exijitu zitzaien.

Jakinik ekimena honetan parte hartuko zuten kide gehienak mediku egoiliarrak zirela, lankide zaharragoak eta gure nagusiak egunerokotasunean modu indibidualean gehiegi konfrontatu behar ez izateko aurretik aipaturiko baldintza konkretuetara mugatu genuen eskaria. Hala ere, aipatu behar da aipatzen diren paziente mota dela urgentziatako zerbitzu gehienetako ohikoena, eta kasu askotan baldintza horietatik kanpo ere eman izan dira, beti ere ia ezkutuka.

Hala, eskaera publikoa egin genion pazientegai orori, langile orori, eta euskal herritar orori: larrialdietan alta-txostena euskaraz eskatu. Kasu askotan ezin izango genuke gure nahia bete, baina eskari handiagoak beharra normalizatuko luke, argiago eginez zerbitzu euskaldunen bermearen beharra.

Gurea dena defendatzeko jarri ginen lanean: euskaraz, eta ez besterik, idazteko eskubidea. Euskaraz, Euskal Herrian. Emaitzak ez genituen kontabilizatu: nahi baino txosten gutxiago izan ziren, seguru. Ez genuen zerbitzu ezberdinetan dinamika txertatzea lortu, alde nabaria baitago zerbait egiteko debekurik ez izan eta zuzendaritzatik datorren agindu bat ez betetzearen artean. Hala ere, balorazio oso positiboa egin genuen: euskaraz idatzi daiteke aurretik idatzi ez den esparruetan, eta esparru guztiak ditugu oraindik arakatzeko. 
Eskura genituen aurreidatziak gure kasa itzuli eta igo behar izan genituen plataformara. Araba ESIko euskara zerbitzua, beti bezala, laguntzeko prestutasun osoz. Proposamenari hasieratik ezezkoa, bideragarria ez eta gehiegizkoa zelako. Itzulpenean eta difusioan laguntzarik ez. Behin Euskaraldia bukatuta, txostenak euskaraz idatzi zituzten langileen zerrenda eskatu zuten, txostenak barne, pazienteen oniritzirik gabe. Txapak eta kartelak nonahi, baina arlo klinikoan ez ezazue sekula euskara sartu.

Azpimarratzekoa da lankide euskaldun askoren aurkakotasunezko jokabidea: beldurra, lankide espainolekiko konplizitatea, egingarritasunarekiko zalantzak... baita zuzendaritza ezberdinen aurrean proposamena atzera botatzeko saiakerak. Horiek bai, euskaldun zintzoak.

Konponbidea, txostenak egitea eta aurreidatziak itzultzea baino latzagoa izan arren, begi bistan dugu epe luzera begirako dinamika: euskaraz lan egin, euskaraz formatu, MIR azterketaren egituraketa aldatu, kontratazioan euskara baldintza bihurtu gehigarri beharrean (espainola eta frantsesaren gisan), eta osasun egituretan euskara hegemonizatzea, bai administratiboki eta bai pertsonal aldetik. Orobat, osasun arretan pazientea erdigunean jartzea, euskaldunak albo batera utzi gabe, euskaldunen osasuna kaltetu gabe."

Hortaz, pazientegai orori, langile orori, eta euskal herritar orori honako gonbita luzatzen diogu: Larrialdietara joatean, eska dezatela alta-txostena euskaraz. Larrialdietatik haratago ere, egin diezaietela eskaera beren osasun administrazioei arreta euskaraz eskaini eta komunikazio kliniko idatzia ere euskaraz emateko. Horretarako, Elebideri eta norbere osasungintzako arduradunari (Osakidetza zein Osasunbideari) iradokizun, eskaera, edo kexa bideratuz.

\section{Itzulbide}

Itzultzaile automatikoaren proiektuak urteak daramatza martxan. Hala ere, egoeraren analisi egokirik gabe lan antzua egiteak, osasungintza eta euskalgintza antzu eta kaltegarri batera garamatza. la Osakidetza bezain zaharra den euskalgintza antzua.

Osasun arretan berdintasunak osasun zerbitzuetarako sarbide bera, beharrekiko erabilera bera eta arreta kalitate bera eskatzen ditu. Komunikazio mugek eta segurtasun kultural faltak arriskuan jartzen dute ekitate hau. Gizarte elebidun batean hizkuntza minorizatua hitz egiten duen pazienteak ez du komunikatzeko gaitasun eta erraztasun bera edukiko osasun hornitzaile ez elebidun batekin edo bere komunitateko kide batekin (edo gutxienez bere lehen hizkuntza dakien norbaitekin).

Berdintasunaren bilaketak arazoen identifikazio bibliografikoa, ikerketa eta konponbidea ekarri behar ditu. Zalantzagarriak izan daitezkeen edota ebidentzian oinarriturik ez dauden konponbideak garatu aurretik komunitateen beharrak identifikatu behako lirateke. Osasun ikerketek gold estandarren arabera eta jarraiki funtzionatu beharko lukete, eta ez metodologia korapilatsu edo ez zientifikoaren arabera.

Komunitateak beren osasun arretako hizkuntza beharren identifikazio eta konponbide planifikazioan inplikatu behar dira, segurtasun kulturala eta eskaintza aktiboaren eredua jarraitu nahi bada. Bestela, pazienteen ongizatea osasun arretaren horniduran inplikaturiko industria ezberdinen (informatika, farmazeutikak, etab.) lehentasun ekonomiko edo bestelako lehentasun teorikoek ordezkatuko dezakete, pazientearengan zentraturiko eredutik aldenduz.

Komunitate elebidun ezberdinetan eman daitezkeen identifikatu gabeko beharren diagnosi eta planifikazioa eskatzen du ikerketaren etikak, soilik egungo gold estandarrak hobetu edota berdintzeko asmoa duten alternatibak eskaintzeko. Bere burua errespetatu nahi duen edozein hizkuntza edo kultura programak ezin dezake bere burua hizkuntza mugen etsipenezko konponbideak bilatzera mugatu, egun gaiaren inguruan dagoen ebidentzia kontuan hartu gabe.

Makina bidezko edo automatikoak diren itzultzaileek ez dute osasun arretan beren kontura ezartzeko eraginkortasun, zehaztasun edo egokitasunik erakutsi, nahiz eta hizkuntza mugen kasuan tresna osagarri gisa erabil daitezkeen. 
Itzulpena ez da aukera egokia ingurune elebidunetarako, non ez dagoen hizkuntza mugarik. Hizkuntza parekotasuna da komunikaziorako kulturalki segurua den espazioak sortzeko bidea, non itzulpena azken aukera gisa gorde beharko litzatekeen. Itzultzailearen kalitatea gorena izanik ere, ez du inondik inora osasun arreta estandar onenera iristeko baldintzarik betetzen. Ez ditu Pazienteen segurtasuna eta gogobetetasuna hobetuko duen edo ez aurreikusten.

Hizkuntza mugak dela eta, egungo gold estandarra hizkuntza parekotasuna da giza itzultzailea baino, bitarteko gabeko komunikazio zuzen eta osoa ematea ahalbidetzen baitu osasun langile eta pazienteen artean.

Osasun sistemek konpetentzia kulturala, segurtasun kulturala, pazientearengan zentraturiko arreta eta hizkuntza parekidetasuna txertatu beharko lituzkete abangoardiako kontzeptu gisa hizkuntza mugei aurre egitean.

Horixe baita itzultzaile automatikoak frogatu behar duena: ez itzulpena egiteko tresna egokia denik, pazienteen segurtasuna eta osasun kalitate onena bermatzen duela baizik.. Itzulbidek zera erakusten du: Osakidetzaren Euskara Planak ez direla ebidentzian oinarritzen, ez dituztela pazienteak edota klinikoak aintzat hartzen. Medikuntzatik at dauden teknikari batzuek Osakidetzako zuzendaritza erdaldun baten neurrira egindako plangintzak baino ez dira.

Itzulbide helburu zehatz batekin ernaldu da: euskarazko testu librea gaztelerara itzuli, euskaraz sortu nahi ditugun eremuak erdaldunduz. Hortaz, ez du langileak edota osasun ikasleak euskara ikastera, praktikatzera edota hobetzera animatzen; euskaraz dagoen eremu urria gazteleraz eskainiko baitzaie, langile erdaldunak bakean eta lasai bizi daitezen. Hau da, osasun profesionalen euskara ezagutza ezinbesteko egin beharrean, hautazko bihurtzen du. Hori horrela izanik, ez ditu hizkuntza dinamika hegemonikoak iraultzen, ezta pazienteen euskarazko arretarik bermatzen. Aitzitik, euskaraz ez dakiten profesionalak kontratatzea ahalbidetzen du, bai UEMAko udalerrietan, bai euskararen arnasgune izan daitezkeen beste eremuetan.

Orain arte euskaraz idatzi ez duten horiek hasiko dira, Itzulbide proiektuari esker, buru-belarri euskararen alde, euren burua zuritzeko. Euskaraz idazteko eskubidea onartuko zaigu, jakinda euskara ez dela inoiz ere derrigorrezkoa izango, ezta pazientearekin euskaraz egitea ere. Gure bazterrean, ez diogu inori trabarik sortuko. Baliteke epe motzera euskaraz idazteko lasaitasun handiagoa izatea, baina euskara hautazko hizkuntza bilakatzen badugu, egungo gaixotasuna kronifikatzera kondenatuta gaude.

Ekimena honek, funtsean, euskaltzale otzanak, sagardotegiko eta mendiko euskaltzaleak, baina lan esparruko losintxariak lasaitzeko baino ez du balio.

Ausazkoa omen den ekimena, Osakidetzaren esparru osora zabaldua, zenbait langile euskara hutsean lanean hasi eta hilabete eskasetara. Pazienteei txosten klinikoak euskaraz ematen hasi eta berehala euskaraz ez dakiten horiei ikasteko beharra kendu nahi diegu. Hortaz, euskararen beharra kentzea Osakidetzaren proiektu estrategikoa dugu egun. Zuzendaritzak ez du etsitzen. Guk euskaraz idazten duguna erdaraz nahi du.

Espainiera derrigorrezko ezagutzazkoa egin, lanerako exijitu, unibertsalizatu eta estandarizatu. Euskaraz ezin formatu, ikasi, artatu, ezta lan egin ere. Ez dira ikasketak euskalduntzen, ikasketa euskaldunekin ez da euskara maila nahikoa ziurtatzen, ikasketa erreminta oro espainieraz, baita formazio espazioak eta langileen arteko kolaborazioak ere. Ez zaie pazienteei aktiboki galdetzen zer hizkuntzatan artatuak izan nahi duten, ez dira euskarazko zirkuituak martxan jartzen, baina beti izango dute espainiera eskura administrazioarekin duten edozein arazo konpontzeko.

Euskaltzale "tradizionalak», esku bat euskaltzaletasun indibiduala goraipatzeko dauka eta bestea administrazio espainiar eta frantsesei bostekoa emateko. Egizue euskaraz lasai, gainerakoei emango baitizkiegu tresnak berau jakin gabe zuek idatzitakoa ulertzeko. Ur txikitako euskaltzaleak, arazoaren muinari eta sakontasunari heldu gabe norberaren azaleko kontzientzia garbitu nahi dutenak, esparru ofizial orotan euskara marjinala den bitartean. Euskal idazle baten hitzei jarraiki: "subordinaziotik 
sistema ezin dela aldatu ohartzen direnean halako bipolaritate patxadatsu batean bizitzen saiatzen diren horiek daude, errealitateak etengabe ukatzen dizkien hitzak eta mezuak erabiliz galeriara begira, eta de facto menpekotasuna onartuz erabaki praktiko guztietan. “

Bada euskarazko osasun corpusa, graduetan zehar ikasia, nahiz eta graduak ere hein handi batean espainolez bukatu. Arazoa lan esparruan dago, non guztiz espainolez funtzionatzen den. Hizkera teknifikazio ikastaroek ez dute ezertarako balio gradua bera euskaldundu gabe edota lan egiteko esparruak landu gabe.

Osasun langile euskaldunak gara, ez itzultzaileak. Ez gaude atzerrian, utzi diezagutela gure herriko, Euskal Herriko pazienteei arretarik onena (euskarazko arreta) ematen.

Konponbidea epe luzerako plangintza egitean datza, eta hurrengo puntuetan laburbiltzen ditugu osasun egituretan euskara normalizatzeko proposatzen ditugun lan-ildoak:

Itzulbide proiektua behin-behinean etetea hurrengo proposamenak garapen bidean jarri arte:

- Ikasketak eta formazioa euskara hutsean egiteko aukera bermatu.

- Hizkuntza zientifiko-teknikoa euskaratu eta estandarizatu.

- Froga osagarriak eta proba diagnostikoak euskaraz jaso.

- Esparru formal orotan euskaraz idazteko aukera ziurtatu: ibilbide elebidunen gisako formatuak landuz adibidez. Osasun arreta maila guztietan, lehen mailatik espezializatura, euskarazko zerbitzu integrala eskainiko duten profesionalen katea.

Euskaraz ikasi nahi dugu. Pazienteak euskaraz artatu nahi ditugu. Euskaraz azaldu nahi ditugu gure ondoezak gaixoaldian. Osasungintzako paziente, ikasle eta langileak gara eta osasungintza euskalduntzera gatoz. 